\title{
Ultrastructure of Egg Chorion of Vulnerable Species Morimus funereus Mulsant, 1862 (Coleoptera: Cerambycidae)
}

\author{
Hassas Tür Morimus funereus Mulsant, 1862'un Yumurta \\ Koriyonunun İnce Yapısı
}

\author{
Research Article \\ Derya Çiftçi \\ Department of Biology, Science Faculty, Gazi University, Teknikokullar, Ankara, Turkey.
}

\section{A B S TR AC T}

\begin{abstract}
n this study, the egg chorion of Morimus funereus Mulsant, 1862 is examined. M. funereus, xylophagus and saproxylic species, accelerate the nutrient transformation of forests by separating dead trees. This species is categorised in "VU (Vulnerable)" on the IUCN Red List of Threatened Species and also included in European Habitats Directive. A female specimen of M. funereus was collected from Eskişehir in 2012. The specimen was laid in a laboratory environment. The eggs are whitish cream, oval-fusiform in shape. Polygon patterns (pentagons and hexagons) are visible on the egg surface on SEM images. Two micropyles, one at the anterior pole and the other at the posterior pole, occur in the egg. The micropylar areas are spongiform with pores of various sizes. Chorionic structure and micropylar area of the egg are quite different from other Cerambycidae species eggs. Egg surface morphology of M. funereus can be used as basis for further studies and as a tool to compare other species of Morimus.
\end{abstract}

\section{Key Words}

Morimus funereus, egg, chorionic structure, vulnerable species.

\section{öz}

u çalışmada, Morimus funereus Mulsant, 1862'un yumurta koryonu incelendi. Ksilofagus ve saproksil tür olan M. funereus, ölü ağaçları ayırarak ormanların besin dönüşümünü hızlandırır. Bu tür IUCN Nesli Tükenme Tehlikesi Altında Olan Türlerin Kırmızı Listesi'nde “VU (Hassas) kategorisinde yer almaktadır ve ayrıca Avrupa Habitat Direktifi'nde de yer almaktadır. M. funereus bir dişi örneği Eskişehir'den 2012 yılında toplanmıştır. Örnek laboratuvar ortamında yumurtlamıştır. Yumurtalar beyazımsı krem, oval-iğsi şekildedir. Yumurta yüzeyinin SEM görüntülerinde poligon desenler (beşgenler ve altıgenler) görülmektedir. Yumurtada biri anterior diğeri posteriorda olmak üzere iki mikropil yapısı bulunmaktadır. Mikropil bölgeleri, çeşitli büyüklükte delikleri olan süngerimsi şekildedir. Yumurtanın koryon yapısı ve mikropil bölgesi diğer Cerambycidae türlerinin yumurtalarından oldukça farkıdır. M. funereus'un yumurta yüzey morfolojisi ilerideki çalışmalar için temel olabilir ve Morimus türlerini karşılaştırmada kullanılabilir

\section{Anahtar Kelimeler}

Morimus funereus, yumurta, koryonik yapı, hassas tür.

Article History: Received: Jan 30, 2018; Revised: Feb 22, 2018; Accepted: Jul 31, 2018; Available Online: Oct 4, 2018.

DOI: 10.15671/HJBC.2018.239

Correspondence to: D. Çiftçi, Department of Biology, Science Faculty, Gazi University, Teknikokullar, Ankara, Turkey. 


\section{INTRODUCTION}

Crambycid eggs and first-instar larvae are rarely encountered by the casual collectors. The medium of oviposition varies widely from in the soil or in the dead stems of grasses and herbaceous plants to deep in the bark of trees. Usually the eggs are well hidden under bark scales or in slits in the bark, and they are usually laid in wood that seasoned or decaying [1]. For these reasons, relatively few egg chorion descriptions of cerambycid eggs have been recorded. Hernández (1990 and 1991) examined the morphological and chorionic structures, polar regions of eggs of many Iberian cerambycid species $[2,3]$. Ciach and Michalcewicz (2009) gave description of the egg morphology of Rosalia alpine that collected from Poland [4]. Candan et al. 2007, Suludere et al. 2007 and Suludere et al. 2010 briefly described chorionic structures of eggs of respectively Agapanthia osmanlis (collected from Bayburt province, TR), Rhaesus serricollis (collected from Osmaniye province, TR) and Batocera rufomaculata (collected from Osmaniye province, TR) [5-7]. It is seen that egg morphology studies are very few compared to the known number of Cerambycid species (more than 35.000 ) in the world [8].

Xylophagous insects play a multifunctional and very important role in forest ecosystems [9]. Xylophagous species accelerate the nutrient transformation of forests by separating dead trees [9]. Morimus funereus Mulsant, 1862 (Cerambycidae) is one of the xylophagus beetles and also it is a stenotopic, silvicolous (growing in or inhabiting woodlands), xylodetriticolous (living in decayed wood), xylophagous (eating wood) and saproxylic species at the same time $[10,11]$.

This cerambycid beetle is on and in the rotten, moist stumps, in the wood lying on soil surface and in trunks with the remaining bark of Fagus, Quercus, Populus, Castanea and Abies $[10,12]$. Vrezec et al., 2010 more frequently collected $M$. funereus on stumps or wood of Quercus sp. and Abies alba, but less than Fagus sylvatica and Picea abies. Also, the species showed differences in nutrient selection in the laboratory environment Sambucus, Juglans, Quercus, Alnus, Populus and Tilia tree species [13].
According to data from entomological collections, the species is active between March and September. Additionally, the adults can hibernate during their two-year lifespan [12]. Biology and ecology of $M$. funereus is quite poorly known and there has been a few paper publish about this subject $[12,14]$.

The larvae of this beetle are inner bank (phloem) feeders, found in the trunks and old stumps of some deciduous trees. Larval development of Morimus funereus is 3-4 years [12]. In general, it is known that the species is daytime active animal attracted to freshly cut down wood and stumps, where it also lays eggs, predominantly in the spring [11]. M. funereus is flightless and also it is not known exactly population status, distribution, ecology and biology, for this reasons it is categorized in "VU (Vulnerable)" on the IUCN Red List of Threatened Species. Also species is included in European Habitats Directive (Annex II: Animal and Plant Species of Community Interest Whose Conservation Requires the Designation of Special Areas of Conservation).

Also, there is no complete and sufficient data on population and density of vulnerable cerambycid $M$. funereus in Turkey. According to Özdikmen (2012), this species recorded 15 provinces (Amasya, Ankara, Antalya, Bilecik, Bolu, Bartın, Bursa, Çanakkale, Düzce, Eskişehir, Kırklareli, Kocaeli, Karabük and Tokat) from Turkey [15]. It seems that the specimen numbers collected in the given records are few.

To date, the egg morphology of Morimus funereus hasn't been described. The purpose of the present work is to describe the egg morphology of $M$. funereus. It is also thought that the results of this study will be used as a comparison material in egg morphology studies of other Morimus species to be made in the future.

\section{MATERIALS and METHODS}

A female Morimus funereus was found on the ground. The specimen was collected from Eskişehir in 2012 (locality information: Eskişehir, Tepebaşı, between Uludere-Behçetiye villages, $1240 \mathrm{~m}, 10$. IV.2012). The specimen was placed 
in a $20 \times 20$ plastic container in a laboratory environment and fed with seasonal vegetables. The specimen was laid about 30-40 eggs in the laboratory environment. The eggs were placed in $70 \%$ alcohol within 24 hours. The eggs were in air dried after dehydration with ethanol and were mounted with double-sided tape on SEM stubs. Eggs coated with gold and were examined with a Jeol JSM 5600 SEM.

\section{RESULTS}

It has been determined that Morimus funereus laid eggs usually in the evening or at night times in laboratory conditions. The eggs are whitish cream, oval-fusiform in shape (Figure 1) and measuring approximately $4.93 \mathrm{~mm}$ in length and
$2,08 \mathrm{~mm}$ in width. Polygon patterns (pentagons and hexagons) are visible on the egg surface (Figure 2). These polygonal patterns become more and more evident towards the anterior and posterior poles (Figures 3-6). At the center of the polygons located near the posterior pole are distinct aeropiles (Figures 5-6) on the contrary polygons located near the anterior pole. The aeropiles located in the center of the egg are sparse and are observed at very high magnitudes (x5000 and above). Two micropyles, one at the anterior pole (Figures 7-8) and the other at the posterior pole (Figures 9-10), occur in the egg. The micropylar areas are spongiform with pores of various sizes. The micropylar diameter at the anterior pole is greater than posterior.

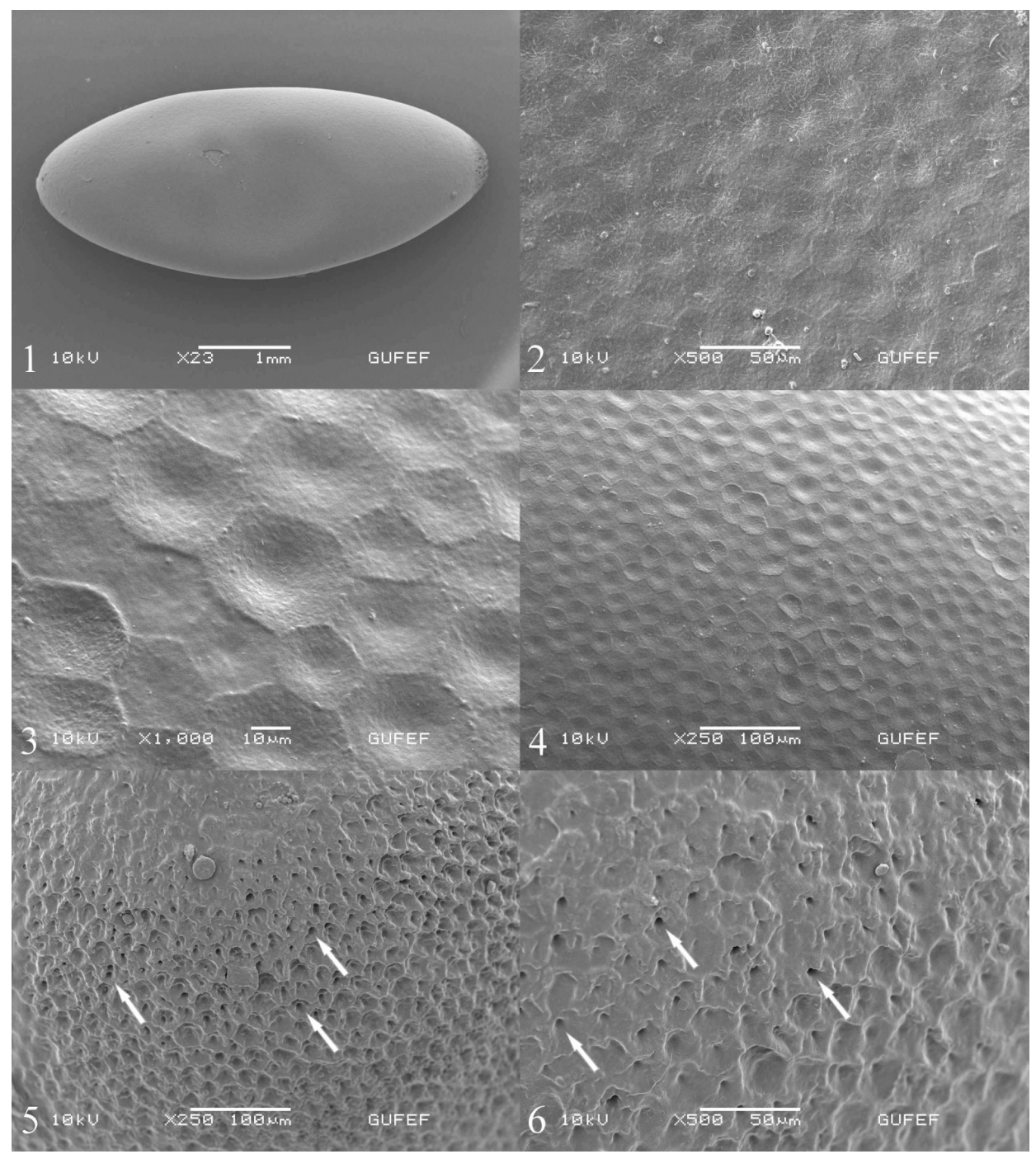

Figure 1. General view of an egg of Morimus funereus, 2. Polygon patterns (middle of the egg), 3. and 4. Polygon patterns close to anterior pole of the egg, $\mathbf{5}$. and $\mathbf{6}$. Polygon patterns close to posterior pole of the egg and aeropyles (shown by arrows). 


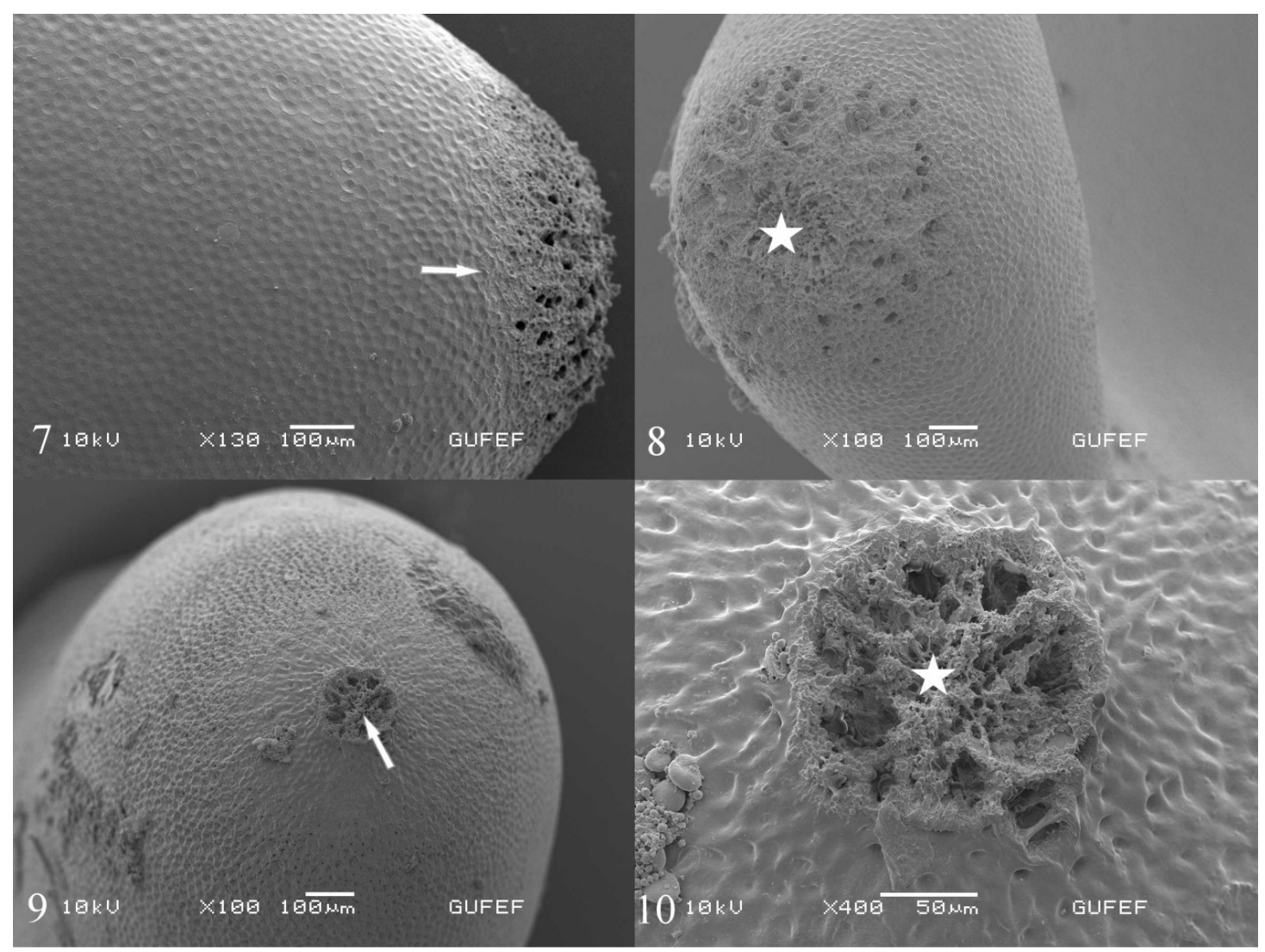

Figures 7. and 8. Anterior pole of the egg showing micropylar area (shown by arrow and star), 9. and 10. Posterior pole of the egg showing micropylar area (shown by arrow and star).

\section{DISCUSSION}

Morimus funereus is in the VU (Vulnerable) category on the IUCN Red list, because of unknown population status, distribution and contributing to forest ecology. With this study, the egg morphology of species was detail examined by SEM. Egg surface structure and micropylar area are quite different from other Cerambycidae species (See other publications that written in the references). The egg chorion serves as a most important feature to study the taxonomic and phylogenetic diversity as the ootaxonomy is concerned with the external chorionic patterns for the identification of species and intraspecific taxa [16]. The egg morphology of other Morimus species has not been investigated until now. So that, with the study of egg morphology of other Morimus species, egg surface morphology can be used as a distinctive character.

\section{Acknowledgments}

I wish to thank to Şirin Bahar KARAHASAN CAN helping me feed the specimen and Gazi University, Science Faculty for providing SEM facilities.

\section{References}

1. L.M. Gardiner, Egg Bursters and Hatching in the Cerambycidae (Coleoptera), Can. J. Zoo., 44 (1966) 199-212.

2. J.M. Hernández, Description of the eggs of Iberodorcadion endemic species in Guadarrama Mountains (Spain) (Coleoptera, Cerambycidae, Lamiinae), Bol. R. Soc. Esp. Hist. Nat. (Sec. Biol.), 86 (1990) 161-179.

3. J.M. Hernández, Study of the characters of the egg in some Iberian Cerambycidae and taxonomic interest (Coleoptera), Graellsia, 47 (1991) 49-59.

4. M. Ciach, J. Michalcewicz, Egg Morphology of Rosalia alpine (Linnaeus, 1758) (Coleoptera: Cerambycidae) from Southern Poland, Entomological News, 120 (2009) 61-64.

5. S. Candan, Z. Suludere, G. Tozlu, Description of Surface Structure of Egg and First Instar Larvae of Agapanthia osmanlis Reiche and Saulcy, 1858 (Coleoptera: Cerambycidae), XVIII. Ulusal Mikroskopi Kongresi Özet Kitabı, 213 (2007).

6. Z. Suludere, H. Özdikmen, S. Candan, S. Turgut, External Morphology of Eggs of Rhaesus serricollis (Motscgulsky, 1838) (Coleoptera: Cerambycidae: Prioninae), XVIII. Ulusal Mikroskopi Kongresi Özet Kitabı, 306 (2007). 
7. Z. Suludere, H. Özdikmen, S. Candan, S. Turgut, Batocera rufomaculata (Degeer, 1775) yumurta ültrastrüktürü (Coleoptera, Cerambycidae, Lamiinae), 20. Ulusal Biyoloji Kongresi, (2010).

8. P. Švácha, J.F. Lawrence, Cerambycidae Latreille, 1802, In: Leschen R.A.B., Beutel R.G. (eds). Handbook of Zoology, Arthropoda: Insecta; Coleoptera, Beetles, Vol. 3: Morphology and Systematics (Phytophaga), 77177, Walter de Gruyter, Berlin, (2014).

9. C. Bucşa, I. T uşan, Preliminary Data on Xylophagous Beetles (Insecta: Coleoptera) from the "Breite Ancient Oak Trees" Nature Reserve (Sighişoara, Romania), Brukenthal. Acta Musei, 3 (2010) 593-606.

10. M. Jurc, N. Ogris, R. Pavlin, D. Borkovic, Forest as a Habitat of Saproxylic Beetles on Natura 2000 Sites in Slovenia, Rev. Ecol. (Terre Vie), 63 (2008) 53-66.

11. A. Vrezec, Š. Ambroži, A. Kapla, An overview of sampling methods tests for monitoring schemes of saproxylic beetles in the scope of Natura 2000 in Slovenia, Saproxylic beetles in Europe: monitoring biology and conservation Abstracts Book, 73-90 (2012).
12. B. Dojnov, Z. Vuj i, N. Boži, A. Margeti, M. Vuji, V. Nenadovi, J. Ivanovi, Adaptations to captive breeding of the longhorn beetle Morimus funereus (Coleoptera: Cerambycidae); application on amylase study, J. Insect Conserv., 16 (2012) 239-247.

13. A. Vrezec, A. Vrezec, Š. Ambroži, A. Kapla, Biology and ecology of flightless cerambycid Morimus funereus (Mulsant, 1862) as a background for monitoring application: laboratory and large-scale field study, $6^{\text {th }}$ European symposium and workshop on the conservation of saproxylic beetles, 20 (2010).

14. S. Polak, Phenology and mating behavior of Morimus funereus (Coleoptera, Cerambycidae), $6^{\text {th }}$ European symposium and workshop on the conservation of saproxylic beetles, 19 (2010).

15. H. Özdikmen, Longhorned Beetles of Düzce Province in Turkey (Coleoptera: Cerambycidae), Mun. Ent. Zool. 7 (2012) 714-731.

16. L.H. Margaritis, M. Mazzini, Structure of the egg. In: Harrison F.W. (ed.). Microscopic Anatomy of Invertebrates, Vol.11C: Insecta 995-1037, Wiley-Liss Inc., New York, (1998). 